\title{
Opinions of Primary Education Programme Students on the Development of Competence for Teaching Effective Learning Strategies and Methods
}

\author{
Vlasta Hus, Minka Koprivnik \\ University of Maribor, Faculty of Education, Maribor, Slovenia \\ Email:vlasta.hus@um.si,minka.koprivnik1@um.si
}

How to cite this paper: Hus, V., \& Koprivnik, M. (2016). Opinions of Primary Education Programme Students on the Development of Competence for Teaching Effective Learning Strategies and Methods. Creative Education, 7, 2193-2201.

http://dx.doi.org/10.4236/ce.2016.715216

Received: August 10, 2016

Accepted: September 17, 2016

Published: September 20, 2016

Copyright $\odot 2016$ by authors and Scientific Research Publishing Inc. This work is licensed under the Creative Commons Attribution International License (CC BY 4.0).

http://creativecommons.org/licenses/by/4.0/

\begin{abstract}
In this article, we present the results of an empirical study, in which we attempt to study how primary education programme students assess their own competencies for teaching their pupils effective learning strategies and methods, and what time they consider is the most appropriate for such teaching. To acquire this data, we used an anonymous questionnaire. The sample included 305 students from Faculties of Education in Slovenia. We determined that most students felt competent enough to teach various learning strategies and that students thought that the best time to begin teaching pupils about effective learning was during the 1st educational period.
\end{abstract}

\section{Keywords}

Learning to Learn, Teaching, Competences, Students of Primary Education

\section{Introduction}

The key competencies, which the Official Journal of the European Union (2006) also defines as competencies whose development should be promoted in pupils and students, also include the learning-to-learn competency. The European Commission has recommended that all European Union members include this competence in curriculums on all levels of education. The learning-to-learn competence has been defined as the ability to learn and to pursue one's own learning, to know how to organise learning, and to manage the time and information, either individually or in groups. Amalathas (2010) states that the learning-to-learn competence enables an individual to pursue independence, lifelong learning, the ability to achieve the learning goals set, knowledge 
for selecting the strategies and methods for effective learning, confidence in one's self, the ability to learn with others and from others, ... and that it represents an important factor for achieving effective results, as is corroborated by numerous researchers on the basis of conducted studies (Marentič Požarnik, 2007; Licardo, 2009; Wall, 2012; Sagitova, 2014; Peculea, 2015).

Since the learning-to-learn competence does not develop automatically, educators represent an important factor in the transfer of these skills (Licardo, 2009). Educators, who strive towards directing students in their learning process, provide counselling, and encourage their independence in learning, have an important role in the effective development competence in students (James et al., 2006; Sagitova, 2014; Peculea, 2015).

The question of when is appropriate to introduce various learning methods and strategies to students often appears in expert literature on the subject. Even though an unambiguous answer cannot be found to this question, it is important that we do not miss or overdo this period, while the abilities and developmental level of children have to be taken into consideration (Marentič Požarnik, 2012). All the above-mentioned factors and strategies can be included in early education in all subjects, whereby the development of effective learning strategies and methods must be intentional and included in the curriculum for all subjects (Marentič Požarnik, 2006).

Even in the early education process, educators can provide pupils with numerous diverse purposeful activities that allow the pupils to learn independently, as well as provide guidance on the learning methods and strategies to increase the effectiveness of learning. Sladoje-Bošnjak (2011) states that knowledge on how to learn and which strategies should be employed in learning represents one of the most important skills, since the accumulation of information and the acquisition of an ever-increasing amount of knowledge do not ensure better knowledge and success in a particular field. Students who are aware of their capabilities and which problem-solving strategies are necessary in a specific situation and how they should be used are more successful in learning and solving of various problems (Peklaj, 2000).

Marentič Požarnik (1988) also warns that, in addition to knowing the effective learning strategies, all educators should be aware of the main factors of effective learning, and should consider them in their work and familiarise students in this regard. We feel that we must emphasise the importance of motivation, categorised among internal psychological factors, which determines the thoroughness of learning and the quality of results achieved (Marentič Požarnik, 2003).

In addition to the motivation, it is necessary to teach the students how to manage the time available for learning. Research so far has shown that numerous students do not know how to manage the time available for learning, so it is very important to teach students how to organise their time and form plans for learning (Binder, Keller, \& Thiel, 1999; Caruth, 2014). In addition to the abovementioned, we must also emphasise the importance of appropriately organised and stimulating environment for learning, as learning can only take place effectively and without interruptions in such an environment.

McCormick (2006) states that it is difficult to teach students about effective learning 
methods without the educators themselves having sufficient knowledge on the subject. Unfortunately, previous findings (McCormick, 2006; Delač Felda, 2012) indicate that educators and students (Peculea, 2015) do not possess sufficient expertise and do not know many learning strategies, nor do they know how to include such strategies in specific subjects of study.

Since students of primary education programme will be the ones to pass on the knowledge on effective learning methods and strategies to their pupils, thereby enabling or disabling them to get successes in effective learning, we are interested whether students attending pedagogic faculties in Slovenia (Faculty of Education in Maribor, Ljubljana and Primorska) assess themselves as sufficiently competent for teaching pupils about effective learning strategies and methods, and get their opinion on when is the right time and which basic school subjects they consider are appropriate for passing said knowledge to the pupils. We want to determine if there are any differences between students regarding specific opinions, in terms of faculties and the average grade in the previous year.

Note: A broader presentation of the research results is available in the work of Koprivnik (2015).

\section{Methodology}

The study was based on descriptive and causal non-experimental method of empirical pedagogical research. In the study, there were 305 ( $4^{\text {th }}$ year level 1 and $1^{\text {st }}$ year level 2$)$ students included who studied in the programme of Primary Education at the faculties of education in Slovenia (Faculty of Education in Maribor, Ljubljana and Primorska) in the academic year 2014/2015.

To acquire this data, we used an anonymous questionnaire, which included questions on general information on students and their average grade in the previous year, as well as a five-point descriptive scale for assessment of their own learning methods. In the second part, the students filled out a questionnaire with rating scale answers to assess their own competence (ability) for teaching pupils about effective learning strategies and methods, and questions (closed, semi-open) about what they consider the suitable time to begin educating pupils about learning to learn in basic school.

The data was analysed using the SPSS statistics software, using the frequency distribution (f, f\%) of responses and the $\chi^{2}$-test of hypothesis of independence.

Table 1 shows that we included 118 participants from the University of Ljubljana, which represents $38.7 \%$ of the entire sample, and 117 participants from the University of Maribor, which represents $38.4 \%$ of the entire sample. The share of participating students from the University of Primorska is the smallest and represents $22.9 \%$ of the entire sample (70 participants).

Table 2 shows that as many as 198 students (64.9\%) achieved an average grade of $8.00-8.99$ in the 2013/14 school year. The proportions of students that achieved an average grade of $9.00-10.00(18.7 \%)$ and those that achieved an average grade of 6.00 $7.99(16.4 \%)$ in the previous year are similar. 


\section{Results}

First, we examined how the students of the faculties of education assess the competence for teaching pupils about effective learning strategies and methods.

Results in Table 3 have shown that $77 \%$ of students assess their competence for teaching pupils effective learning strategies and methods as good or very good. Less than a third of students assess their competence for teaching effective learning strategies and methods as neither good nor bad and as very bad, bad.

Below we present the results of the analysis of statistically significant differences of assessment of competence for teaching pupils about effective learning strategies and methods by faculty, by average grade in the previous year and by assessment of one's own method of learning during studies.

Results of the $\chi^{2}$-test in Table 4 have shown that there is no statistically significant difference in the assessment of competence for teaching pupils about effective learning

Table 1. Number (f) and percentage (f\%) of students by faculty.

\begin{tabular}{ccc}
\hline Faculty & f & f\% \\
\hline University of Maribor & 117 & 38.4 \\
University of Primorska & 70 & 22.9 \\
University of Ljubljana & 118 & 38.7 \\
Entire sample & 305 & 100 \\
\hline
\end{tabular}

Table 2. Number (f) and percentage (f\%) of students by average grade in the previous year.

\begin{tabular}{ccc}
\hline Last year's average learning achievement & $\mathbf{f}$ & $\mathbf{f} \%$ \\
\hline $6.00-7.99$ & 50 & 16.4 \\
$8.00-8.99$ & 198 & 64.9 \\
$9.00-10.00$ & 57 & 18.7 \\
Entire sample & $\mathbf{3 0 5}$ & $\mathbf{1 0 0}$ \\
\hline
\end{tabular}

Note: For the purposes of analysis, we combined the categories of average grade between $6.00-6.99$ and $7.00-7.99$, listing them as a combined category of $6.00-7.99$.

Table 3. Number (f) and percentage (f\%) of students by assessment of competence for teaching pupils about effective learning strategies and methods.

\begin{tabular}{ccc}
\hline Assessment of competence for teaching & $\mathbf{f}$ & $\mathbf{f} \%$ \\
\hline Very bad, bad & 5 & 1.6 \\
Neither good nor bad & 65 & 21.3 \\
Good & 206 & 67.5 \\
Very good & 29 & 9.5 \\
Entire sample & $\mathbf{3 0 5}$ & $\mathbf{1 0 0 . 0}$ \\
\hline
\end{tabular}

Note: For the purposes of analysis, we combined the categories of very bad and bad in a single category very bad, bad. 
strategies and methods by faculty; nevertheless, smaller differences occurred, indicating that the students from the University of Primorska are the only ones to assess themselves with the grade very bad, bad (5.7\%).

The value of chi-squared indicates a statistically significant difference in the assessment of competence for teaching pupils about effective learning strategies and methods by average grade in the previous year.

Table 5 shows that the students who rated their competence for teaching effective

Table 4. Results of the $\chi^{2}$-test of differences of assessment of competence for teaching pupils about effective learning strategies and methods by faculty.

\begin{tabular}{|c|c|c|c|c|c|c|}
\hline & & & \multicolumn{3}{|c|}{ Faculty } & \multirow{2}{*}{$\begin{array}{l}\text { Entire } \\
\text { Sample }\end{array}$} \\
\hline & & & $\begin{array}{c}\text { University of } \\
\text { Maribor }\end{array}$ & $\begin{array}{c}\text { University of } \\
\text { Ljubljana }\end{array}$ & $\begin{array}{c}\text { University of } \\
\text { Primorska }\end{array}$ & \\
\hline \multirow{8}{*}{$\begin{array}{l}\text { Assessment of } \\
\text { competence for } \\
\text { teaching }\end{array}$} & \multirow{2}{*}{ Very bad, bad } & $\mathrm{f}$ & 1 & 0 & 4 & 5 \\
\hline & & $\mathrm{f} \%$ & $0.9 \%$ & $0.0 \%$ & $5.7 \%$ & $1.6 \%$ \\
\hline & \multirow{2}{*}{$\begin{array}{l}\text { Neither good } \\
\text { nor bad }\end{array}$} & $\mathrm{f}$ & 29 & 25 & 11 & 65 \\
\hline & & $\mathrm{f} \%$ & $24.8 \%$ & $21.2 \%$ & $15.7 \%$ & $21.3 \%$ \\
\hline & \multirow{2}{*}{ Good } & $\mathrm{f}$ & 75 & 82 & 49 & 206 \\
\hline & & $\mathrm{f} \%$ & $64.1 \%$ & $69.5 \%$ & $70.0 \%$ & $67.5 \%$ \\
\hline & \multirow{2}{*}{ Very good } & $\mathrm{f}$ & 12 & 11 & 6 & 29 \\
\hline & & $f \%$ & $10.3 \%$ & $9.3 \%$ & $8.6 \%$ & $9.5 \%$ \\
\hline \multirow{2}{*}{\multicolumn{2}{|c|}{ Entire sample }} & $\mathrm{f}$ & 117 & 118 & 70 & 305 \\
\hline & & $\mathrm{f} \%$ & $100.0 \%$ & $100.0 \%$ & $100.0 \%$ & $100.0 \%$ \\
\hline
\end{tabular}

$\chi^{2}=10.925, P=0.091$

Table 5. Results of the $\chi^{2}$-test of differences of assessment of competence for teaching pupils about effective learning strategies and methods by average grade in the previous year.

\begin{tabular}{|c|c|c|c|c|c|c|}
\hline & & & \multicolumn{3}{|c|}{$\begin{array}{l}\text { Last year's average } \\
\text { learning achievement }\end{array}$} & \multirow{2}{*}{ Entire Sample } \\
\hline & & & $6.00-7.99$ & $8.00-8.99$ & $9.00-10.00$ & \\
\hline \multirow{8}{*}{$\begin{array}{l}\text { Assessment of competence } \\
\text { for teaching }\end{array}$} & \multirow{2}{*}{ Very bad, bad } & $\mathrm{f}$ & 0 & 4 & 1 & 5 \\
\hline & & $\mathrm{f} \%$ & $0.0 \%$ & $2.0 \%$ & $1.8 \%$ & $1.6 \%$ \\
\hline & \multirow{2}{*}{$\begin{array}{l}\text { Neither good } \\
\text { nor bad }\end{array}$} & $\mathrm{f}$ & 18 & 36 & 11 & 65 \\
\hline & & $\mathrm{f} \%$ & $36.0 \%$ & $18.2 \%$ & $19.3 \%$ & $21.3 \%$ \\
\hline & \multirow{2}{*}{ Good } & $\mathrm{f}$ & 28 & 143 & 35 & 206 \\
\hline & & $\mathrm{f} \%$ & $56.0 \%$ & $72.2 \%$ & $61.4 \%$ & $67.5 \%$ \\
\hline & \multirow{2}{*}{ Very good } & $\mathrm{f}$ & 4 & 15 & 10 & 29 \\
\hline & & $\mathrm{f} \%$ & $8.0 \%$ & $7.6 \%$ & $17.5 \%$ & $9.5 \%$ \\
\hline \multirow{2}{*}{\multicolumn{2}{|c|}{ Entire sample }} & $\mathrm{f}$ & 50 & 198 & 57 & 305 \\
\hline & & $\mathrm{f} \%$ & $100.0 \%$ & $100.0 \%$ & $100.0 \%$ & $100.0 \%$ \\
\hline
\end{tabular}

$\chi^{2}=13.119, P=0.041$ 
learning strategies and methods as higher achieved a relatively higher average grade in the previous year than those students who assess their teaching competence as lower.

The highest proportion of students who rated their competence for teaching effective learning strategies and methods as neither good nor bad is represented by students who achieved an average grade of 6.00 - 7.99 (46\%). The students who assessed their competence as good predominantly achieved an average grade of $8.00-8.99(72.2 \%)$, while the students who assessed their competence as very good predominantly achieved an average grade of $9.00-10.00(17.5 \%)$.

The results of chi-squared indicate a statistically significant difference in the assessment of competence for teaching pupils about effective learning strategies and methods by assessment of one's own method of learning during studies.

The results in Table 6 show that the students who assess their competence for teaching effective learning strategies and methods as neither good nor bad pre-dominantly (54.5\%) assess their own method of learning as very bad, bad. The students who assessed their competence as good predominantly (74.9\%) assessed their method of learning as good, while the students who assessed their competence as very good predominantly (37\%) assessed their method of learning as very good.

With the research we also wanted to examine what are students' opinions on the appropriate time to begin teaching pupils about learning to learn.

The results in Table 7 have shown that the majority of students $(51.8 \%)$ consider the first educational period as the most appropriate time to begin teaching pupils about learning to learn, while none of the students think that the secondary period or later is appropriate for this purpose.

Table 6. Results of the $\chi^{2}$-test of differences of assessment of competence for teaching pupils about effective learning strategies and methods by assessment of one's own method of learning during studies.

\begin{tabular}{|c|c|c|c|c|c|c|c|}
\hline & & & \multicolumn{4}{|c|}{ Assessment of one's own way of learning } & \multirow{2}{*}{$\begin{array}{l}\text { Entire } \\
\text { Sample }\end{array}$} \\
\hline & & & $\begin{array}{l}\text { Very bad, } \\
\text { bad }\end{array}$ & $\begin{array}{c}\text { Neither good } \\
\text { nor bad }\end{array}$ & Good & Very good & \\
\hline \multirow{8}{*}{$\begin{array}{l}\text { Assessment of } \\
\text { competence for } \\
\text { teaching }\end{array}$} & \multirow{2}{*}{ Very bad, bad } & $\mathrm{f}$ & 0 & 4 & 0 & 1 & 5 \\
\hline & & $\mathrm{f} \%$ & $0.0 \%$ & $5.9 \%$ & $0.0 \%$ & $3.7 \%$ & $1.6 \%$ \\
\hline & \multirow{2}{*}{$\begin{array}{l}\text { Neither good } \\
\text { nor bad }\end{array}$} & $\mathrm{f}$ & 6 & 20 & 37 & 2 & 65 \\
\hline & & $\mathrm{f} \%$ & $54.5 \%$ & $29.4 \%$ & $18.6 \%$ & $7.4 \%$ & $21.3 \%$ \\
\hline & \multirow{2}{*}{ Good } & f & 4 & 39 & 149 & 14 & 206 \\
\hline & & $\mathrm{f} \%$ & $36.4 \%$ & $57.4 \%$ & $74.9 \%$ & $51.9 \%$ & $67.5 \%$ \\
\hline & \multirow{2}{*}{ Very good } & f & 1 & 5 & 13 & 10 & 29 \\
\hline & & $\mathrm{f} \%$ & $9.1 \%$ & $7.4 \%$ & $6.5 \%$ & $37.0 \%$ & $9.5 \%$ \\
\hline \multirow{2}{*}{\multicolumn{2}{|c|}{ Entire sample }} & $\mathrm{f}$ & 11 & 68 & 199 & 27 & 305 \\
\hline & & $\mathrm{f} \%$ & $100.0 \%$ & $100.0 \%$ & $100.0 \%$ & $100.0 \%$ & $100.0 \%$ \\
\hline
\end{tabular}

$\chi^{2}=42.074, P=0.000$. 
Table 7. Number (f) and percentage (f\%) of students by opinion on the appropriate time to begin teaching pupils about learning to learn.

\begin{tabular}{ccc}
\hline The most appropriate time & $\mathbf{f}$ & $\mathbf{f} \%$ \\
\hline Preschool period & 16 & 5.3 \\
First educational period & 158 & 51.8 \\
Second educational period & 113 & 37.0 \\
Third educational period & 18 & 5.9 \\
Secondary period or later & 0 & 0 \\
Entire sample & 305 & $\mathbf{1 0 0}$ \\
\hline
\end{tabular}

\section{Discussion and Conclusion}

The purpose of our study was to study how students of primary education programme assessed their own competence for teaching students on effective learning strategies and methods, and how the assessment of said competence varied by faculty and the average grade in the previous year. We were also interested in when was the most appropriate time that students thought about to start teaching pupils about effective learning methods and strategies.

Results have shown that students predominately consider their competence for teaching pupils effective learning strategies and methods as good, since a majority grade of their own competence is good. The latter results are encouraging, as research conducted so far on the samples of educators (Delač Felda, 2012; Magajna, 1996) indicates that they lack the sufficient expertise on the relevant competence and do not know many learning strategies. Delač Felda (2012) additionally states that educators face a problem of how to even start such teaching, since they are not confident about their acquired knowledge on learning strategies. Based on our data, we can assume that the findings indicate that students-future educators-will pass their knowledge to pupils due to their feeling of suitable competence on the knowledge of learning strategies and methods. However, even though it seems that participating students will acquire sufficient knowledge and skills to teach pupils about effective learning strategies and methods-at least according to their own opinion, we can express some doubt about the veracity of self-assessment in comparison to the actual situation. Since the assessment of competence is a complex concept that is difficult to measure and grade with the basic methods of data collection, we think that such a study on a sample of students needs to be repeated, thereby forming new, more objective measuring instrument, which would enable both a quantitative and qualitative view of the actual situation of students' competence.

When analyzing the competence assessment for teaching pupils about effective learning strategies and methods by faculty, we determine that faculties dedicate similar attention to the development of said competence in students. This is corroborated by the conducted study (Koprivnik, 2015), which, based on study plans for a primary education programme of three pedagogic faculties (Pedagoška fakulteta v Mariboru, Pedagoška fa- 
kulteta v Ljubljani, Pedagoška fakulteta na Primorskem), reviewed and compared set goals and competencies, as well as projected study grades, that the students should develop and acquire by the end of a specific subject course. It is determined that the number of study courses that should enable the development of the aforementioned competence is proportionally equal on all three pedagogic faculties. Nevertheless, the study emphasises (Koprivnik, 2015) that strategies and factors of learning-to-learn competence, which should be developed by students, are largely defined indirectly, and that plans for individual study courses should be designed to include concrete goals and instructions on how pass this knowledge to students, whereas professors and educators should be provided additional education regarding this subject.

The students who rated their competence for teaching effective learning strategies and methods as higher achieved a relatively higher average grade in the previous year. We can assume that students who achieve a higher average grade during their studies are more familiar with the various ways, methods, and strategies of learning, which also contribute to their success. Due to their better knowledge in this field and higher average grade, these students most likely consider themselves more competent and believe they can pass their knowledge acquired and used during their study to pupils in the classroom.

The question of when is appropriate to introduce various learning methods and strategies to students often appears in expert literature and the educational system. The research shows that the students believe that education on this subject should begin as early as possible, to ensure the development of effective learning. Their response to the question "When do you believe is the right time to start teaching pupils about how to learn?" shows that they consider the first educational period as the most appropriate. Even though the presented question does not have a direct answer, we believe that educators can begin familiarising children (with adjustments to developmental characteristics) with various possibilities on this subject in early, starting grades of basic school by posing simple questions (e.g. What do you know about the task? How long did it take you to solve it? How do you learn best? How do you arrange your learning environment? etc.); however, the educators must know how to appropriately motivate the pupils and promote independent learning, and include their parents in this process.

The presented results provide interesting data on the development of competence for teaching effective learning strategies and methods with students of primary education programmes. The study raises an interesting issue in contemporary teaching and can be used as an incentive for further studies in the field of competence for transferring knowledge about effective learning methods and strategies, as well as their integration into individual primary school subjects.

\section{References}

Amalathas, E. (2010). Learning to Learn in Further Education. Reading: CfBT Education Trust. http://www.campaign-for-learning.org.uk/cfl/assets/documents/Research/LearningToLearn_v 5FINAL.pdf

Binder, A., Keller, G., \& Thiel, R. (1999). Spreminjanje učnih navad. Ljubljana: Center za 
psihodiagnostična sredstva, d.o.o.

Caruth, G. (2014). Learning How to Learn: A Six Point Model for Increasing Student Engagement. Participatory Educational Research (PER), 1, 1-12.

http://dx.doi.org/10.17275/per.14.06.1.2

Delač Felda, D. (2012). Vpeljevanje kompetence učenje učenja v pouk. InS. Kmetič et al. (Eds.), 1. mednarodna Konferenca o učenju in poučevanju matematike (pp. 299-302). Ljubljana: Zavod Republike Slovenije za šolstvo.

James, M., Black, P., Carmichael, P., Conner, C., Dudley, P., Fox, A., Frost, D., Honour, L., MacBeath, J., Marshall, B., McCormick, R., Pedder, D., Procter, R., Swaffield, S., Wiliam, D. (2006). Learning How to Learn: Tools for Schools. London and New York: Routledge.

Koprivnik, M. (2015). Nekateri vidiki kompetence učenje učenja pri študentih razrednega pouka.Magistrsko delo. Maribor: Univerza v Mariboru, Pedagoška fakulteta.

Licardo, M. (2009). Učenje učenja. In S. Zavrl et al. (Eds.), 4. letna konferenca Kakovost za prihodnost vzgoje in izobraževanja (pp. 18-21). Ljubljana: Slovenski institut za kakovost in meroslovje.

Magajna, L. (1996). Kvalitativne značilnost in interaktivni procesi, ki vodijo do uspešnega učenja in izvajanja. In B. Marentič Požarnik (Ed.), Zbornik posveta; Kakovost preduniverzitetnega izobraževanja (pp. 31-34). Maribor: Zavod Republike Slovenije za šolstvo,.

Marentič Požarnik, B. (1988). Dejavniki in metode uspešnega učenja. Ljubljana: DDU UNIVERZUM.

Marentič Požarnik, B. (2003). Psihologija učenja in pouka. Ljubljana: DZS.

Marentič Požarnik, B. (2006). Uveljavljanje kompetenčnega pristopa terja vizijo, pa tudi strokovno utemeljeno strategijo spreminjanja pouka. Vzgoja in izobraževanje, 37, 27-33.

Marentič Požarnik, B. (2007). Vloga mentorja pri spodbujanju profesionalne rasti študentov prihodnjih učiteljev. In: C. Peklaj (Ed.), Mentorstvo in profesionalna rast učiteljev (pp. 5-15). Ljubljana: Center za pedagoško izobraževanje Filozofske fakultete Univerze v Ljubljani.

Marentič Požarnik, B. (2012). Psihologija učenja in pouka; Temeljna spoznanja in primeri iz prakse. Ljubljana: DZS.

McCormick, R. (2006). Learning to Learn: Learning, Teachers and Schools. In: U. Fredrikkson, \& B. Hoskins (Eds.), Learning to Learn Network Meeting Report, Report from the Second Meeting of the Network (pp. 38-42) Ispra: CRELL.

Official Journal of the European Union (2006). http://eur-lex.europa.eu/LexUriServ/LexUriServ.do?uri=OJ:L:2006:394:0010:0018:EN:PDF

Peculea, L. (2015). Curricular Openings in Developing the Learning to Learn Competency: An Intervention Program for 11th Graders with Learning Difficulties. Procedia Social and Behavioral Sciences, 209, 370-377. http://dx.doi.org/10.1016/j.sbspro.2015.11.252

Peklaj, C. (2000). Samoregulativni mehanizmi pri učenju. Sodobna Pedagogika, 51, 136-149.

Sagitova, R. (2014). Students' Self-Education: Learning to Learn across the Lifespan. Procedia Social and Behavioral Sciences, 152, 272-277. http://dx.doi.org/10.1016/j.sbspro.2014.09.194

Sladoje-Bošnjak, B. (2011). Teacher's Psyhic Characteristics and Student's Metacognitive Strategies. In V. Kadum (Ed.), Monografija međunarodnog znanstvenog skupa I. dio; Suvremene strategije učenja i poučavanja (pp. 285-294). Pula: Sveučilište Jurja Dobrile, Odjel za odgojne i obrazovne znanosti.

Wall, K. (2012). It Wasn't Too Easy, Which Is Good If You Want to Learn: An Exploration of Pupil Participation and Learning to Learn. The Curriculum Journal, 23, 283-305. http://dx.doi.org/10.1080/09585176.2012.703442 
Submit or recommend next manuscript to SCIRP and we will provide best service for you:

Accepting pre-submission inquiries through Email, Facebook, LinkedIn, Twitter, etc. A wide selection of journals (inclusive of 9 subjects, more than 200 journals)

Providing 24-hour high-quality service

User-friendly online submission system

Fair and swift peer-review system

Efficient typesetting and proofreading procedure

Display of the result of downloads and visits, as well as the number of cited articles

Maximum dissemination of your research work

Submit your manuscript at: http://papersubmission.scirp.org/

Or contact ce@scirp.org 